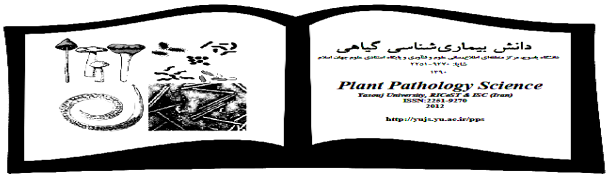

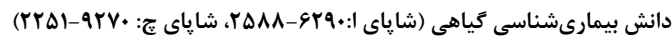

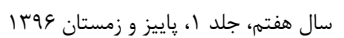

Plant Pathology Science (eISSN:2588-6290, pISSN:2251-9270)

Vol. 7(1), 2018

\title{
Sulfur Role in Plant Diseases Management
}

\section{KAMRAN GHASEMI ${ }^{\otimes}$}

Department of Horticulture, Sari Agricultural Sciences and Natural Resources University, Sari, Iran ( $\square$ : kamranghasemi63@gmail.com)

Received: 08.11.2016

Accepted: 26.04.2017

Ghasemi K. 2018. Sulfur role in plant diseases management. Plant Pathology Science $7(1): 63-72$.

Abstract : Sulfur (S), as a promoter of plant defense system and fungicidal effect, can have a critical role in organic farming. Presence of sulfuric defense compounds including elemental sulfur, $\mathrm{H}_{2} \mathrm{~S}$, glutathione, pytochelatins, secondary metabolites and S-rich proteins are vital under stress conditions. As a soil disinfectant, carbon disulfide is widely used against soil-borne pathogens. This is used for controlling the root and crown rot disease caused by Armillaria. Sulfur fumigation is used against powdery mildew in greenhouse production. Fumigation and application of sulfur pad are methods for controlling the grape and some other fruits rot in storage. Besides, sulfur is effective in control of mites, psyllids, and thrips.

Key words: Organic, Sulfur dioxide, Fungicide, Glutathione

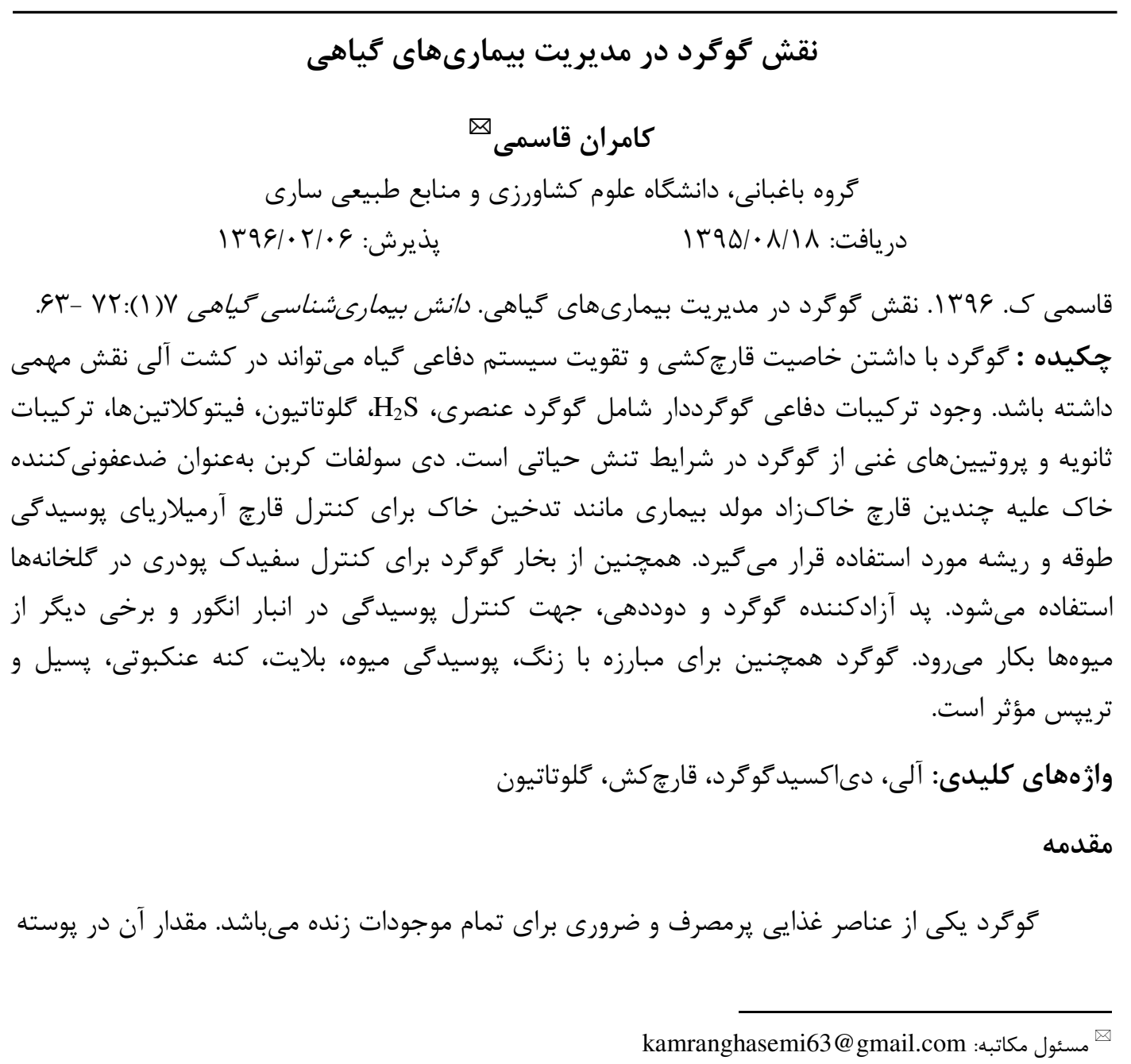




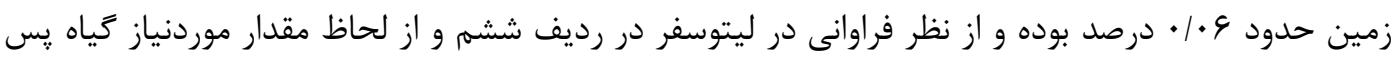

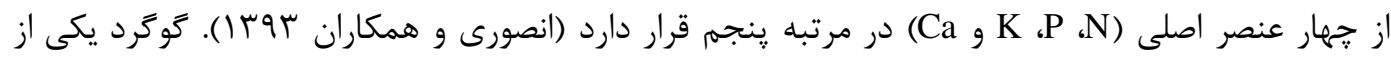
محصولات فرعى پالايشگاههاى كاز و گتروشيمى مىباشد كه در در ايران نيز توليد ساليانه آن به بيش از دو ميليون تن رسيده است. توليد گو گرد مىتواند يكى از معضلات اساسى يالايشگاههاى كشور به شمار آيد اين در حالى است كه بخش عمده خاكهاى كشور آهكى بوده و با مصرف گو گرد و متعاقباً اكسيداسيون آن توسط اكسيدكنندهاى گوكرد، ضمن تأمين سولفات موردنياز گياه، اسيديته در اطراف ريشه در خاى كاهش يافته و كمبود عناصرى مانند روى، فسفر و آهن نيز مرتفع مى

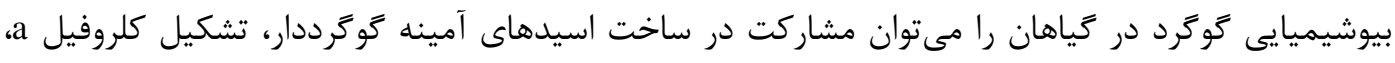
فعال كردن آنزيمهاى تجزيهكننده يروتيين، ساختهشدن بيوتين، تيامين، كلوتامين، كوآنزيم و تشكيل روغنهاى كلوكوزيدى، تشكيل گروههاى دى سولفيدى و سولفيدريل دانست (انصورى و همكاران سوب ). شرط بهرهگيرى از اين توان بالقوه كوگرد، حضور باكترىهاى اكسيدكننده اين ماده در خاك است. اكسايش گوزرد بهطور عمده به روش بيولوزيك انجام مى گيرد كه با توليد اسيد سولفوريك همراه بوده و موجب كاهش اسيديته خاك، آزادسازى عناصر غذايى براى كياه و در نتيجه افزايش عملكرد مى سوس (). استفاده از گوگرد بهمنظور كاهش اسيديته خاكهاى آهكى يكى از كاربردهاى مهم اين عنصر مىباشد كه موجب افزايش قابليت جذب عناصر غذايى شده و در نتيجه مىتواند در سلامت و قدرت كياه تأثير گذار باشد. استفاده از گوگرد و ريزجانداران اكسيدكننده آن بهعنوان يك راهحل زيستى فاقد يِامدهاى مخرب زيست محيطى است كه بهعنوان راهكارى جهت بهبود وضعيت تغذيه گياهان در خاكهاى آهكى و قليايى در سالهاى اخير موردتوجه فراوان قرار گرفته و نتايج خوبى را به همراه داشته است. با عنايت به وجود منابع فراوان كوكرد در كشور و آهكى بودن اكثر خاكها، استفاده از اين ماده ارزان قيمت جهت بهبود تغذيه كياهان سزاوار توجه بيشتر مىباشد. بر همين اساس توصيه شده است كه به علت كاهش زيستتوده ميكروبى بر اثر استفاده زياد گوكرد، از اين عنصر بيشتر از •ه كيلوكرم در هكتار استفاده نشود (رضايى و همكاران 
مىباشد. استفاده از سولفات در شرايط درون شيشهاى براى ايجاد مقاومت عليه قارجهاى بيمارىزاى مختلف مفيد ولى معمولاً عليه باكترىهاى بيماركر بىاثر اعلام شده است. همجنين اثر گوگرد گَازى به شكل سولفيد

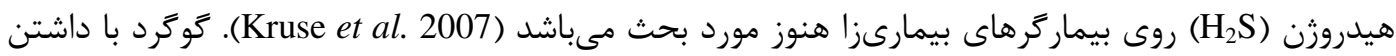
خاصيت قارجكشى و تقويت سيستم دفاعى كياه مىتواند در كشت آلى و توليد محصول سالم مورد استفاده قرار بحَيرد. در اين مقاله بر نقش گوگرد در تقويت سيستم دفاعى گياه و همجنين كاربردهاى رايج آن در مديريت بيمارىهاى قارجى مورد بحث قرار گرفته است. ا- نقش Fو تركيبات دفاعى گو گرددار (Sulfur-containing defense compounds=SDCs) براى زنده ماندن كياهان تحت تنش زيستى و غيرزيستى بسيار حياتى هستند. اين تركيبات شامل گوگرد عنصرى، H. كلوتاتيون، فيتوكلاتينها، تركيبات ثانويه مختلف (مانند كليكوزينولاتها در خانواده كلمها) و يروتيينهاى غنى از گَگرد هستند. زمانى كه گياه در معرض انواع تنش قرار مى گيرد، ساخت تركيبات دفاعى گوگرددار در اثر اسيد جاسمونيك و ساير ييامها افزايش مىيابد كه به نظر مىرسد اين تركيبات تأثير مهمى روى گتانسيل دفاعى گياه داشته باشند. كلوتاتيون، سيتوزول و ساير بخشهاى سلولى را در مقابل گونههاى فعال اكسيرنى كه در شرايط تنش توليد مىشوند، حفاظت مىكند (Rausch and Wachter 2005). در شرايط درون شيشهاى گَگرد در افزايش مقاومت گياه به قارجها تأثير مثبت يا خنثى نشان مىدهد (Kruse et al. 2007). تحقيقى نشان داده كه در واكنش بيماركرهاى گياهى و سوخت و ساز گوگرد، اسيد جاسمونيك بهعنوان ييامرسان نقش دارد (Kruse et al. 2007). تيمار دزهاى بالاى متيل جاسمونات موجب افزايش بيان زنهاى

مرتبط با كو گرد شده و توليد سيستيين و حلوتاتيون را به همراه دارد (Sasaki-Sekimoto et al. 2005). اصطلاح Sulfur-induced resistance) SIR به تقويت مقاومت طبيعى گياهان در مقابل بيمارگرهاى قارجى از طريق تحريك توليد متابوليتهاى گوگرددار اطلاق مى متابوليتهايى كه تركيبات دفاعى گَگرددار ناميده مىشوند مىتوان به تيونينها (Thionins) و ديفنسينها (Defensins) درون شيشه از خود نشان دادهاند. در خياهان تيره كلم (Brassicaceae) فيتوآلاكسينهايى نظير كامالكسين 
توليد مىشود كه همكى گو گرددار هستند (شكل () و نشان داده شده است كه اين تركيبات (Camalexin) اثرات بازدارنده روى باكترىها و قارجها دارند (Ahuja et al. 2012). اسيد آمينههاى سيستيين و ميتونين

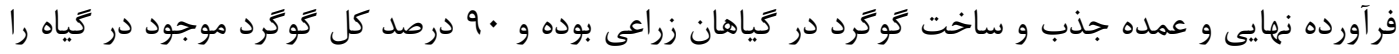
تشكيل مى دهند. اين دو اسيد آمينه از مواد تركيب دهنده بيش از • 9 درصد يروتيينها هستند. اثر ميتونين در القاى مقاومت به سفيدى يودرى ديده شده است. كلوتاتيون يك تركيب غيريروتيينى تيول با وزن مولكولى كم است و ذخيره غيريروتيينى گوگرد احيا شده در گياهان محسوب مىشود. رابطه مثبت بين ميزان اين تركيب و حفاظت در برابر بيمارىهاى قارجى وجود دارد. كلوتاتيون بخشى از سامانه آنتىاكسيدان سلولهاى كياهى بهمنظور جلوَيرى از انواع اكسيزن فعال است كه در پاسخ به تنشهاى زيستى و غيرزيستى ساخته بيش بازهاي فيتوآلاكسينها
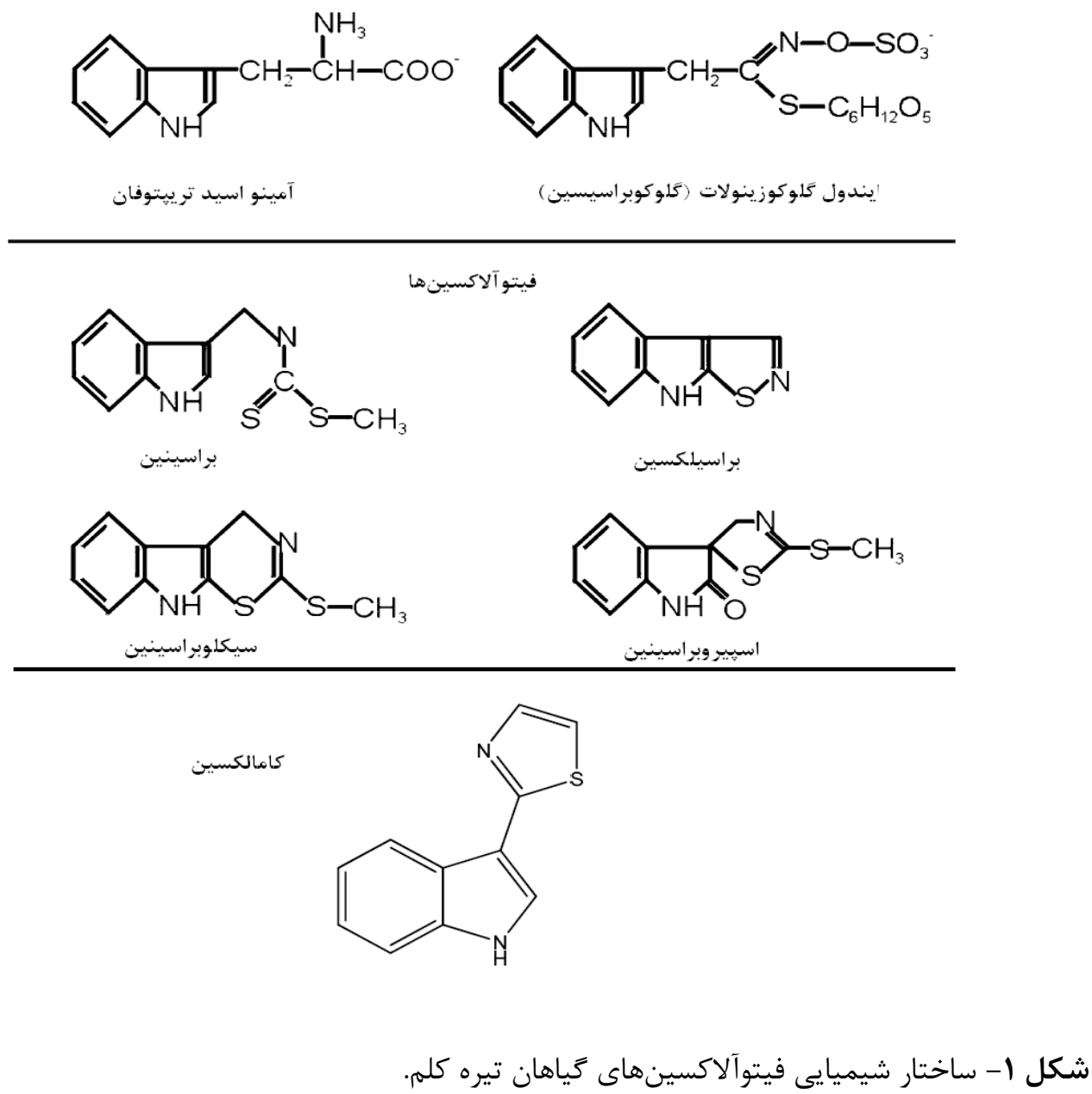

Figure 1. Chemical structure of phytoalexins in Brassicaceae plants. 
مىشوند. به نظر مىرسد اين تركيب در تقويت ديواره سلول با غيرمحلول كردن :رولين و يروتيينهاى ساختمانى غنى از هيدروكسى يرولين در اوايل آلودكى شركت دارد. انواع اكسيرنهاى فعال در علامت انتقال و آغاز سازوكارهاى دفاعى شركت دارند. گياهان با كمبود گو گرد داراى غلظتهاى خيلى كم گلوتاتيون بوده و كوددهى بلشدت محتوى آزاد آن را افزايش مىدهد . تركيبات فرار مانند H2S كه توسط كياهان منتشر مىشود مىتواند آنتىسيبين گياهى باشد يا خروج كازهاى گوكرد احيا شده مىتواند يكى از سازوكارهاى دفاع القايى باشد كه يس از آلودكى فعال مىشود (بنى هاشمى بوب 1).

\section{r- خاصيت قارجكشى تو}

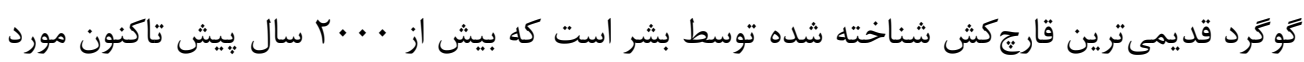

استفاده مىباشد. گفته مىشود اولين بار يونانى ها به اثر گوگرد روى زنگ گندم بیى بردند (Beckerman, BP

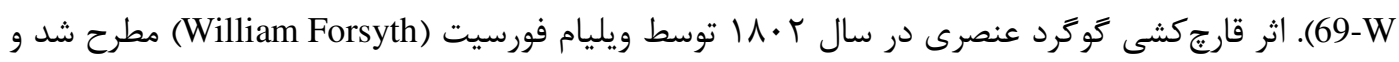
كوگرد بهطور گسترده براى اين منظور در توليدات كشاورزى از اواخر دهه 19 مورد استفاده قرار كرفت. اثر كوگرد عنصرى عليه زنت و سفيدك يودرى ثابت شده است. علاوه بر اثر قارجكشى گوگرد اين عنصر بهعنوان يك كنه كش نيز به كار برده مىشود. در اوايل دهه • 199 ميلادى در ارويا به علت كاهش ميزان گوخرد هوا ناشى از تمهيدات زيستمحيطى، بيمارىهاى قارجى گياهان بلهور قابلتوجهى بهخصوص در اسكاتلند افزايش يافت (Schnug et al. 1995). كو گرد و تركيبات كو گردى بهطور مستقيم بهعنوان يك زيستكش و غيرمستقيم بهعنوان محرى مقاومت كياه و افزايش مقاومت به بيمارىها برشدت بيمارى مؤثر است. دى سولفات كربن بهعنوان ضدعفونى كننده خاى براى جندين قارج خاكزاد مولد بيمارى مانند تدخين خاى براى كنترل قارج آرميلارياى يوسيدگى طوقه و ريشه مورد استفاده قرار مى گيرد. همجنين از بخار گوگرد بهطور معمول براى كنترل سفيدك يودرى در كلخانهها استفاده مىشود. ثابت شده است كه كوددهى گوكرد به خاك به شكل سولفات اثر قابلملاحظهاى در كاهش ميزان و شدت آلودگى به بيمارىهاى قارجى در كياهان زراعى مختلف دارد. در نظامهاى زراعت رايج و بلهيزه زراعت آلى، القا مقاومت با گوگرد (SIR) مىتواند ابزار مؤثرى براى كنترل بيمارى باشد (بنى هاشمى rq ( ). 
تحقيقات مختلف از برهمكنش كوكرد با بيمارىهاى گياهى نظير سفيدى يودرى انكور، جرب معمولى

سيبزمينى، لكه برگى بادامزمينى، لكه سياه آلترناريايى كلزا، يزٔمردىى استوارت ذرت و يزمردگى فوزاريومى كوجهفرنكى گزارش شده است (بنى هاشمى rar 1).

امروزه براى مبارزه با سفيدكيودرى انكَور بهطور گستردهاى از گوَرد استفاده مىشود. از آن جهت كه كوَرد از جوانه زدن هاك قارجها جلوكيرى مى كند، بايد قبل از شيوع بيمارى إعمال شود تا مؤثر واقع

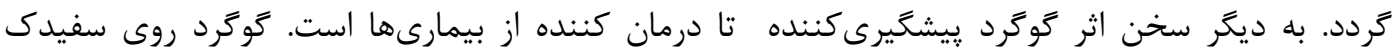

يودرى، يوسيدگى ميوه، كنه تارعنكبوتى، پِيل و ترييس مؤثر است (Beckerman 2016).

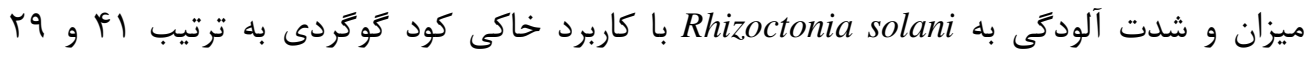
درصد كاهش يافت (Klikocka et al. 2005). همجنين در آزمايش ديخرى تعداد حبههاى آلوده شده به سفيدى يودرى در انكور بعد از افزودن گوخرد به ميزان •م درصد كاهش نشان داد (Bourbos et al. 2000). نتايج يك يزوهش نشان داد كه بوتههاى كلزا حاوى مقدار كافى گوگرد ميزان آلودگى كمترى به

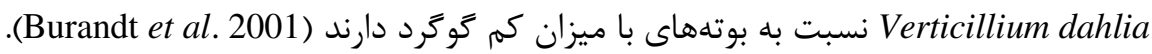
كو گرد عنصرى جربىدوست است و ممكن است بهطور مستقيم وارد ديواره سلول قارج شود. علاوه بر اين كوددهى گوگرد موجب افزايش سطح گلوتاتيون شده و به مقاومت كياه كمك مى كند (بنى هاشمى

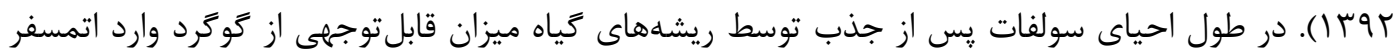
مىشود. خروج گَّرد از گياهان يكساله مانند ذرت و سويا اغلب بلصورت دى متيل سولفيد بوده در صورتى كه درختان خزاندار مقادير برابر H $\mathrm{H}_{2} \mathrm{~S}$ دى متيل سولفيد توليد مى كنند. خروج H $\mathrm{H}_{2} \mathrm{~S}$ از بخشهاى بريده كياه ممكن است .له بار بيشتر از خروج آن از گياهان بدون زخم باشد. خروجىهاى H2S بهعنوان قارجكش

شناخته شده است و بنابراين احتمال دارد يكى از سازوكارهاى مسئول در SIR باشد (بنى هاشمى ז9 ب ). كو گرد را مىتوان به اشكال مختلف يودر وِتابل و گرد تهيه كرد. يكى از انواع مناسب و يركاربرد كوَرد نوعى است كه به آن گُل كَوَرد (Flowers of sulfur) يا گَوَرد تصعيدى مى گوگرد خالص مىباشد (Beckerman 2016). در صورت روغنياشى روى گياهان، بايد دستكمم تا يك ماه از

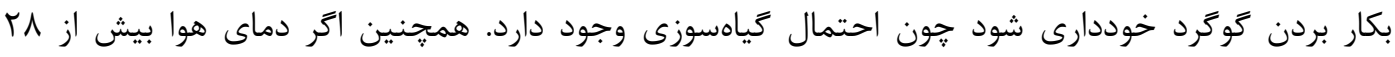


درجه سانتى گراد باشد احتمال كياهسوزى محتمل است. جاليزىها (خيار، كدو، خربزه و هندوانه) به كوگرد حساسيت دارند لذا استفاده از گوگرد در اين گياهان بايد با احتياط بيشترى صورت گيرد. در بين ميوهها نيز زردآلو حساس به گو گرد (Sulfur-shy plant) است (Beckerman 2016).

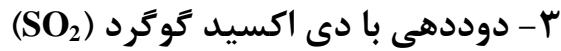

دوددهى (Fumigation) جهت كنترل يوسيدگى ناشى از كيك خاكسترى و ساير يوسيدگىهاى قارجى كه به آهستگى در دماهاى پايين انبار (صفر تا ه/ •- درجه سانتى گراد) رشد كرده و گسترش مىيابند، استفاده مىشود. دى اكسيد گوگرد همجنين از تيره شدن جوب خوشه جلوگيرى مى كند. بايد توجه داشت كه ممكن است غلظت استفاده شده براى دود دادن انكور، براى ساير محصولات مخرب باشد لذا بايد انكورها در محل ايزوله دود داده شوند كه سبزى يا ميوههاى ديكر وجود نداشته باشند. انكورها معمولاً بلافاصله قبل يا بعد از بستهبندى با دى اكسيد گوگرد دوددهى مىشوند و دوباره اين كار بلصورت هفتكى تكرار مىشود. حداقل · · إيىيىام در هر ساعت براى از بين بردن هات و ميسيليومهاى كيكها در صفر درجه سانتى $ا د$

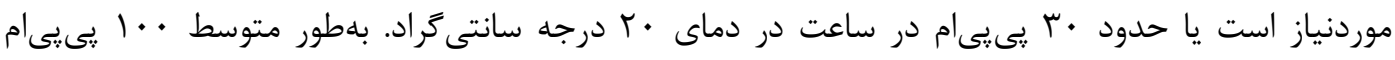

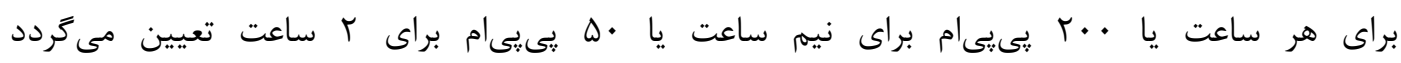
(Crisosto 2008). فرآيند دوددهى بلهورت هفتگى در انبار انجام مى گيرد. بعد از إعمال SO در محيط بسته، فنهايى با سرعت بالا و به مدت سه ساعت روشن مىشوند تا تمامى دى اكسيد گوگرد جذب ميوه، مواد بستلهندى و سطوح انبار شود. در انتهاى دوددهى غلظت دى اكسيد گوگرد نبايد بيشتر از ؟ تا ه يى يىام در هواى انبار باشد و هيجَّونه تخليه و شستشويى نياز نيست. معمولاً جهت اطمينان از اينكه دى اكسيد گوگرد به تمام نقاط رسيده باشد بايد از دزمتر استفاده نمود. دز .1 بيىيىام در ساعت حداقل دز كافى مىباشد. سفيد شدن حبهها مىتواند نشانهاى براى دوددهى زياد باشد. اين حالت بهويزه اگر ميوه در دماى ه/ه/ أا ال درجه به مدت يك تا دو روز باقى بمانند مىتواند به رنگ قهوهاى در بيايد. بايد توجه داشت كه كاز دى اكسيد گَگَرد در غلظتهاى مؤثر، سوزاننده و سمى بوده و حتى مىتواند منجر به مرى شود. حتى

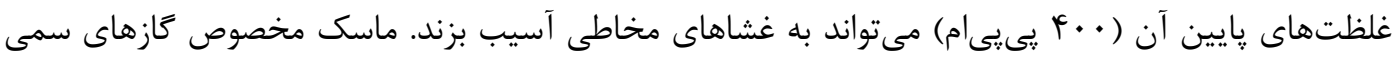
و عينك ايمنى بايد مورد استفاده قرار گيرد. تعداد كمى از مردم ممكن است به باقيمانده گَگرد روى انكور 
واكنش حساسيت نشان دهند لذا ميزان مجاز سولفيت باقيمانده روى ميوه • إيىيىام اعلام شده است كه در صورت بيشتر بودن از اين مقدار قابلفروش و صادر كردن نيست (Crisosto 2008).

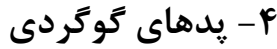

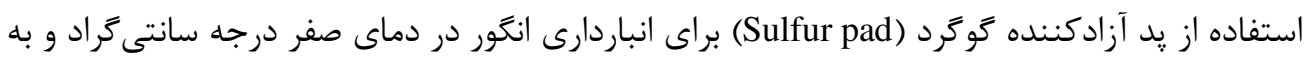

مدت • r ا روز مورد بررسى قرار كرفت كه نتايج نشان داد موجب كاهش معنىدار كيك آبى (Penicillium) و خاكسترى (Botrytis) شده است (Franck et al. 2005). اين نوع گֶ دى اكسيد گوگرد (SO $)$ را بلهتدريج و طى دو تا سه ماه آزاد مى كند. يك يزوهش انجام شده در كشور نشان داد كه بالشتكهاى آزادكننده دى

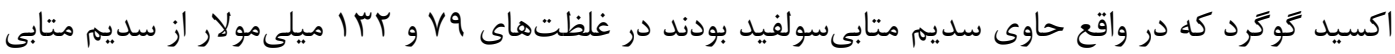
سولفيد، مطلوبترين اثر را از نظر حفظ رنگ ظاهرى و كنترل يوسيدگى خاكسترى در مقاطع زمانى مختلف

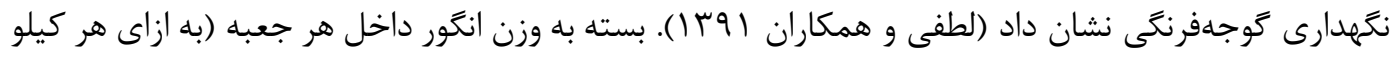
انگور ا گرم سولفوريد) از سولفوريد مناسب (ورقهاى سولفوريد در وزنهاى ه/ه، ل و • ا گرمى در بازار وجود دارند) در جعبه كَاشته مىشود. تمامى اين كارها بهتر است كه در دماى يايين سردخانه انجام كيرد تا از تشكيل قطرات آب روى خوشهها جلو كيرى شود. در اثر واكنش بى سولفيت با رطوبت اتمسفرى، كاز دى اكسيد كوگرد توليد مىشود لذا اگر مقدار رطوبت داخل جعبهها كافى نباشد، آزاد شدن گاز به آهستگى صورت مى جعبهها خيلى بالا باشد آزادسازى گاز خيلى سريع بوده و در نتيجه صدمات زيادى به ميوهها وارد مى گردد. همانطور كه كفته شد كاز دى اكسيد گو گرد باعث مديريت عوامل بيمارىزاى انكور از جمله قارجها مىشود كه از مهمترين عوامل يوسيدكى و كاهش كيفيت انكور در سردخانه مىباشند. وضعيت ظاهرى خوشه و جروكيدگى حبه نيز در تيمار گاز دى اكسيد گو گرد بهبود مىيابد ولى در صورتى كه از غلظت بالاتر از غلظت توصيه شده استفاده گردد باعث ايجاد عوارض نامطلوبى روى ميوه مىشود. سفيدشدهى و طعم نامطلوب حبهها از جمله عوامل نامطلوب غلظت بالاى گوگرد موجود در جعبهها مىباشد. همجنين نتايج حاصل از تحقيقى نشان داده كه مقدار گوگرد بيشتر از حد توصيه شده باعث بالا رفتن غلظت سولفيت داخل ميوه (بيشتر از • إبىيىام) مىشود كه از لحاظ سلامت غذايى براى مصرفكنندكان مضر و عامل محدودكننده در 
صادرات انگور مىباشد (Crisosto 2008).

\section{نتيجه كيرى و وِيشنهاد}

با توجه به توليد زياد گوگرد در كشور از يك سو و بلامانع بودن استفاده از اين عنصر در كشت آلى،

مىتوان از اين منبع ارزان و در دسترس جهت بهبود اسيديته خاكهاى قليايى، تغذيه مناسب گَگرَى، ضدعفونى خاك، مبارزه با انواع بيمارىهاى قارجى بلويزه سفيدكهاى يودرى و كيكهاى انبارى و پِيشگيرى از يوسيدكى ميوهها در طى انباردارى استفاده كرد. در صورت استفاده از اين ماده، علاوه بر صرفهجويى در هزينهها، محصولى سالمتر و عارى از قارجكشهاى شيميايى قابل توليد خواهد بود.

\section{References}

$$
\begin{aligned}
& \text { I. انصورى ع.، غلامى ا.، عباسدخت ح.، قلىيور م.، برادران م. و فلاح نصرت آباد ع. ر. سوسا. بررسى تأثير } \\
& \text { همزيستى ميكوريزايى، كاربرد تيوباسيلوس تيواكسيدانس و گوَرد بر خصوصيات رشد و عملكرد ذرت. }
\end{aligned}
$$

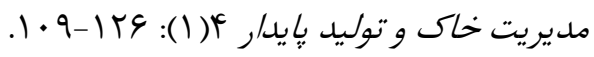

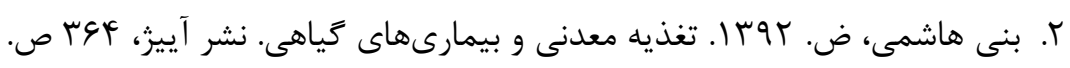

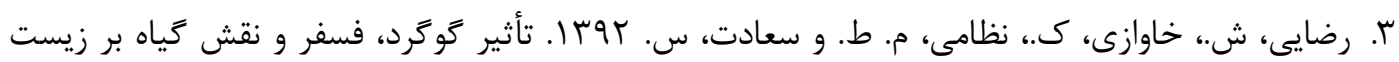

$$
\begin{aligned}
& \text { توده ميكروبى و فعاليت فسفاتازهاى خاك. يزوهش هاى خاك VV r Y): }
\end{aligned}
$$

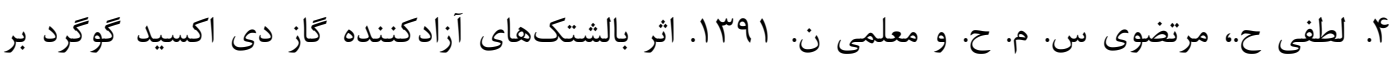

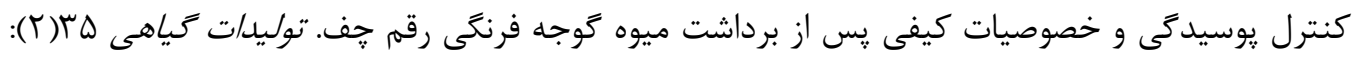

$.90-\vee 9$

5. Ahuja I., Kissen R. and Bones A. M. 2012. اسيديتهtytoalexins in defense against pathogens.

Trends in Plant Science 17:73-90.

6. Beckerman J. 2016. Disease Management Strategies: Using Organic Fungicides. Disease Management Strategies series Purdue University. BP-69-W., https://www.extension.purdue.edu/extmedia/bp/bp-69-w.pdf

7. Bourbos V. A., Skoudridakis M. T., Barbopoulou E. and Venetis K. 2000. Ecological control of grape powdery mildew (Uncinula necator). Http://www.landwirtschaft-mlr.baden wuerttemberg.de/servlet/PB/menu/1043197/index.html 
8. Burandt P., Papenbrock J., Schmidt A., Bloem E., Haneklaus S. and Schnug E. 2001. Genotypical differences in total sulfur contents and cysteine desulfhydrase activities in Brassica napus L. Phyton-Horn 41:75-86.

9. Crisosto C. H. 2008. Grapes, Fumigation with Sulfur Dioxide $\left(\mathrm{SO}_{2}\right)$. WFLO Commodity Storage Manual. http://ucanr.edu/datastoreFiles/234-2689.pdf

10.Franck J., Latorre B. A., Torres R. and Zoffoli J. P. 2005. The effect of preharvest fungicide and postharvest sulfur dioxide use on postharvest decay of table grapes caused by Penicillium expansum. Postharvest Biology and Technology 37: 20-30.

11.Haneklaus S., Bloem E. and Schnug E. 2007. Sulfur interactions in crop ecosystems. pp. 1758. In: M. J. Hawkesford, L. J. De Kok (ed.). Sulfur in Plants an Ecological Perspective. Springer, Germany

12.Klikocka H., Haneklaus S., Bloem E. and Schnug E. 2005. Influence of sulfur fertilization on infection of potato tubers with Rhizoctonia solani and Streptomyces scabies. Journal of Plant Nutrition 28:819-833.

13.Kruse C., Jost R., Lipschis M., Kopp B., Hartmann M. and Hell R. 2007. Sulfur enhanced defense: effects of sulfur metabolism, nitrogen supply, and pathogen lifestyle. Plant Biology 9:608-619.

14.Monde K. and Takasugi M. 1992. High-performance liquid chromatographic analysis of cruciferous phytoalexins using complex ternary mobile phase gradients. Journal of Chromatography 598:147-152.

15.Rausch T. and Wachter A. 2005. Sulfur metabolism: a versatile platform for launching defense operations. Trends in Plant Science 10:503-509.

16.Sasaki-Sekimoto Y., Taki N., Obayashi T., Aono M., Matsumoto F., Sakurai N., Suzuki H., Hirai M. Y., Noji M., Saito K., Masuda T., Takamiya K. I., Shibata D. and Ohta H. 2005. Coordinated activation of metabolic pathways for antioxidants and defense compounds by jasmonates and their roles in stress tolerance in Arabidopsis. The Plant Journal 44:653-668.

17.Schnug E., Haneklaus S., Booth E. and Walker K. C. 1995. Sulphur supply and stress resistance in oilseed rape. In 9th International Rapeseed Congress, Cambridge,UK, 229-231.

18.Smith B., Randle D., Mezencev R., Thomas L., Hinton C. and Odero-Marah V. 2014. Camalexin-induced apoptosis in prostate cancer cells involves alterations of expression and activity of lysosomal protease cathepsin D. Molecules 19:3988-4005. 